\title{
Detection of Toxoplasma gondii and Herpes simplex IgM antibodies in frequently aborted women during different seasons in Mosul
}

\author{
Hisham I. Alkazzaz ${ }^{\star}$, Nadia M. Mahmood ${ }^{\star \star}$, Karam A. Aldabbagh ${ }^{\star \star *}$ \\ * Community Medicine / retired / Nineveh Health Directorate, ${ }^{\star *}$ Dept. of Microbiology/ Ibn-Siena Teaching \\ Hospital, ${ }^{\star \star \star}$ Microbiology/ college of Pharmacy/ University of Mosul/ Mosul / Iraq. \\ Correspondence: karam.ald@gmail.com
}

(Ann Coll Med Mosul 2020; 42 (1):57-61).

Received: $2^{\text {nd }}$ June 2020; Accepted: $15^{\text {th }}$ July 2020.

\begin{abstract}
Background: Many women suffer from frequent abortions due to many causes; one of these causes is infection with different types of microorganisms. Toxoplasma gondii protozoan and Herpes simplex virus (HSV) are well-known causes of repeated abortion. However, it is unclear whether seasonal changes could affect the re-activation of latent infections with these microorganisms.

Objectives: To detect the percentage of active toxoplasmosis and HSV infections among frequently aborted women, and evaluate seasonal changes on such active infection.

Patients and method: Two hundreds women with frequent abortions were tested for anti-toxoplasma gondii IgM antibodies and anti-HSV IgM antibodies in two different seasons (100 patients in summer and 100 patients in winter) and were compared for variance.

Results: For toxoplasmosis, only $2 \%$ of studied women were positive for IgM antibodies in winter in comparison to $3 \%$ in summer with a total active infection of $2.5 \%$ in both seasons; however, for HSV about $12 \%$ were positive in winter and $10 \%$ were positive in summer with a total active infection of $11 \%$ in both seasons.

Conclusion: Seasonal variance showed no significant change on re-activation of latent infection of both Toxoplasma gondii and HSV in frequently aborted women. The rate of infection in frequently aborted women with HSV is higher than the rate of infection with Toxoplasma gondii in Mosul city.
\end{abstract}

Key words: abortion, Herpes simplex virus (HSV), seasonal changes, Toxoplasma gondii, Mosul city, IgM antibodies.

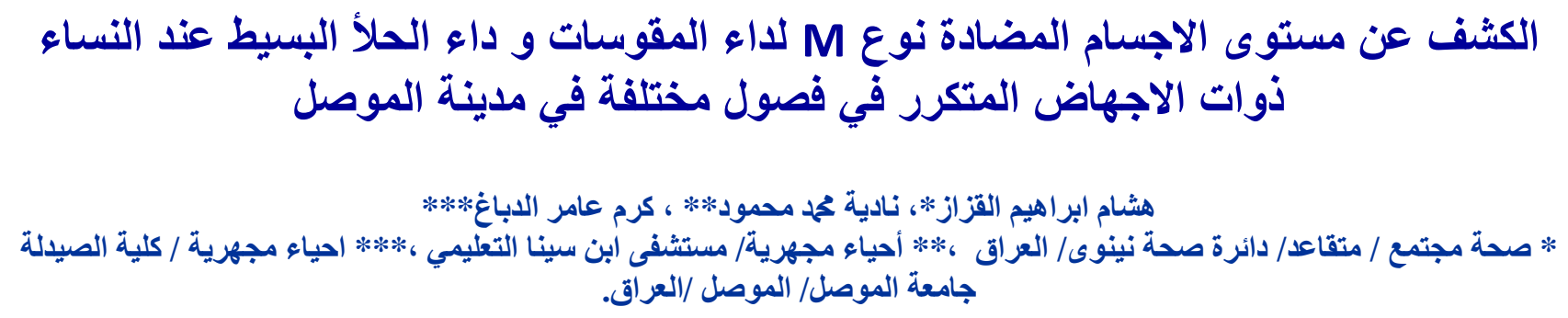

خلفية البحث: يعاني العديد من النساء من اجهاضات منكررة ولعدة اسباب، من هذه الاسباب هو الاصدابات الخمجية بأنواع مختلفة

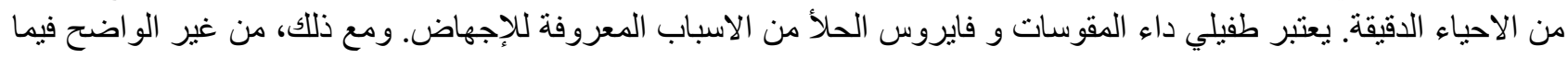

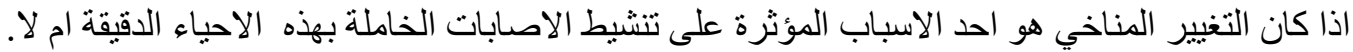

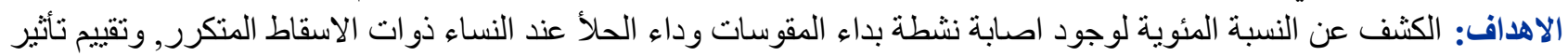
التغيير المناخي على اعادة تنشيط الاصنية بهذه الاحياء الدقيقة. 
المرضى وطريقة العمل: نم جمع بيانات 200 مريضة نعاني من الاجهاض المتكرر، جرى فحصهن لقياس مسنوى الاجسام

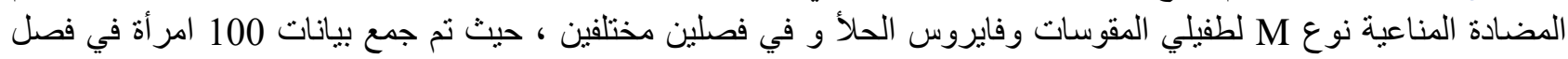

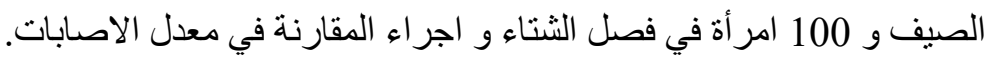

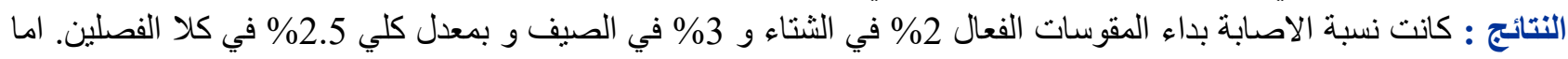

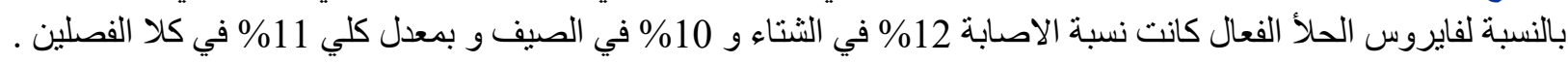

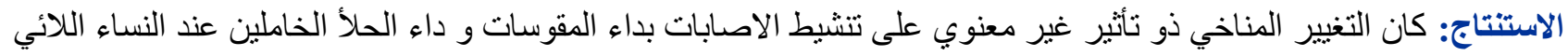

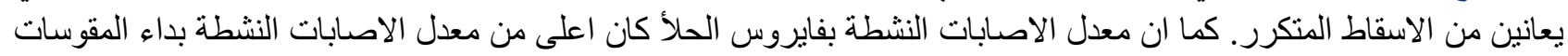
في نفس العينة من المرضى.

الكلمات المفتاحية: الاجهاض، داء المقوسات، داء الحلا، التغييرات الموسمية ، مدينة الموصل، الاجسام المضادة نوع M.

\section{INTRODUCTION}

nfections are well known causes of repeated or frequent abortions with an estimated rate between $4-15 \% .^{1,2}$ These include different types of bacterial, parasitic and viral infections. Herpes simplex virus (HSV) and Toxoplasma gondii are considered to be a risk factor that may cause such pregnancy loss. ${ }^{3,4}$

Both toxoplasmosis and herpes are considered as ubiquitous diseases, affecting all types of population, and manifested differently according to the health status and immunity of infected persons. Both of these diseases will be more aggressive in immune-compromised persons including pregnant women, and child-bearing aged women because they may cause failure of pregnancy.

In one hand, toxoplasmosis can be a major cause of stillbirth and early abortion, due to massive congenital anomalies, and consequent failure to maintain full term pregnancy ${ }^{4}$. On the other hand, HSV is a well-known cause of spontaneous abortion, even if there are no clinical manifestations of the infection. HSV will transfer to the fetus through the placenta, and cause cytopathic changes in different fetal organs. ${ }^{3}$

Many researchers found different epidemiological and pathological factors that affect different groups of population by these microbes, but still, one of the most vulnerable groups is the pregnant women. The rate of infection with these microbes among frequently aborted women in Iraq is relatively high according to many studies conducted in different localities on frequently aborted women. Different research was conducted on toxoplasmosis incidence among frequently aborted women, like a study in Baghdad which showed about $33 \%$ of included women were positive for toxoplasmosis. ${ }^{5}$ Another study conducted in Babylon province showed that there were about $4 \%$ of included women were tested positive. ${ }^{6}$ Whereas a study in Erbil showed that about $13 \%$ of included women were positive for toxoplasmosis. ${ }^{7}$

Many other studies conducted about the distribution of HSV infections among frequently aborted women in different localities in Iraq, like a study conducted in Baghdad city and found that about $50 \%$ of tested women were infected with $\mathrm{HSV}^{8} \quad$ A study conducted in Al-Najaf found that about $30 \%$ of tested women were infected. ${ }^{9}$ In a study conducted in Kirkuk showed that about 24\% of tested women were infected with HSV and $3.2 \%$ had active infection. ${ }^{10}$ Furthermore, another study conducted in Zakho showed that about $77 \%$ of tested women were infected with HSV and $5 \%$ had active infection. ${ }^{11}$

\section{PATIENTS,MATERIALS AND METHODS}

The data in this study were collected from 2010 records of immunology laboratory in Al-Salam teaching hospital in Mosul city/ Nineveh. The patients were all women at child bearing age (2035 years old), suffered from abortion at least once before.

The study included 200 female patients, grouped as 100 patients in winter time (January and February), and 100 patients in summer time (June and July), and the samples were taken accordingly. The rate of infection was compared between winter and summer months to find if there were any seasonal changes. 
No interference was conducted to select patients' data, the included data were kept in the same order as it were conducted and recorded by the laboratory staff.

The included tests were the measurement of anti-Toxoplasma gondii $\operatorname{lgM}$ antibodies and the measurement of anti HSV IgM antibodies in patient's serum by ELISA as referred by the specialized obstetrician; IgM antibodies represent the marker of active infection rather than $\lg G$ antibodies which represent an old or latent infection. All ELISA kits were from bioMerieux Company and ELISA BioTek ELX-800 instrument was used as instructed by the kits insert. The accuracy rate of anti-Toxoplasma gondii $\operatorname{lgM}$ antibodies and anti-HSV lgM antibodies kits is $97.4 \%$ and $97 \%$ respectively. ${ }^{12-20}$

\section{Statistical Analysis}

Statistical analysis in this study was conducted by using Microsoft Excel spreadsheets version 14.0. 2010, using T-test at $p \leq 0.05$ were considered significant.

\section{RESULTS}

For Toxoplasmosis, the results were summarized in Table 1. Overall, out of a total 200 women with repeated abortions, only 5 patients were tested positive for anti-toxoplasma $\operatorname{lgM}$ antibodies comprising $2.5 \%$ of the total number. Meanwhile, the patients number who tested positive in winter season were only 2 out of 100 $(2 \%)$ in comparison $3(3 \%)$ in summer season. Seasonal change was only $1 \%$ higher in winter than in summer (statistically not significant).

Table-1: Anti-Toxoplasma gondii IgM antibodies.

\begin{tabular}{|c|c|c|c|}
\hline Season & $\begin{array}{l}\text { Patients } \\
\text { number }\end{array}$ & $\begin{array}{c}\text { Positive anti- } \\
\text { Toxoplasma } \\
\text { gnodii lgM } \\
(\%)\end{array}$ & $\begin{array}{l}\boldsymbol{P} \\
\text { value* }\end{array}$ \\
\hline Winter & 100 & $2(2 \%)$ & \multirow[t]{2}{*}{0.65} \\
\hline Summer & 100 & $3(3 \%)$ & \\
\hline Total & 200 & $5(2.5 \%)$ & \\
\hline
\end{tabular}

${ }^{*}$ Significant difference at $P \leq 0.05$
For HSV inf3ection, the results were summarized in Table 2. Overall, out of a total 200 women with repeated abortions, only 22 patients were tested positive for anti-HSV-IgM antibodies comprising $11 \%$ of the total number. Meanwhile, the patients number who tested positive in winter season were only 12 out of $100(12 \%)$ in comparison $10(10 \%)$ in summer season. Seasonal change was only $2 \%$ higher in winter than in summer which is statistically not significant.

Table-2: Anti-HSV IgM antibodies

\begin{tabular}{|l|l|l|c|}
\hline Season & $\begin{array}{l}\text { Patients } \\
\text { number }\end{array}$ & $\begin{array}{l}\text { Positive } \\
\text { anti-HSV } \\
\text { IgM (\%) }\end{array}$ & P value \\
\hline Winter & 100 & $12(12 \%)$ & \multirow{2}{*}{0.65} \\
\hline Summer & 100 & $10(10 \%)$ & \\
\hline Total & 200 & $22(11 \%)$ & \\
\hline
\end{tabular}

${ }^{*}$ Significant difference at $P \leq 0.05$

Moreover, only two patients showed positive results for both infections i.e., positive for antiToxoplasma gondii IgM antibodies and for antiHSV IgM antibodies simultaneously.

Finally, the overall results for both anti-toxoplasma and anti-HSV IgM antibodies in women with repeated abortions were compared together for rate variance. The results indicated that the rate of HSV infections is higher than Toxoplasma gondii infections at same period and in same group of population as shown in Table 3.

Table-3: Active toxoplasmosis and active HSV infections in seasonal variance.

\begin{tabular}{|l|l|l|l|}
\hline Season & $\begin{array}{l}\text { Patients } \\
\text { number }\end{array}$ & $\begin{array}{l}\text { Positive anti- } \\
\text { lgM for } \\
\text { Toxoplasma } \\
\text { gondii }\end{array}$ & $\begin{array}{l}\text { Positive } \\
\text { for anti- } \\
\text { lgM for } \\
\text { HSV }\end{array}$ \\
\hline Winter & 100 & $2(2 \%)$ & $12(12 \%)$ \\
\hline Summer & 100 & $3(3 \%)$ & $10(10 \%)$ \\
\hline Total & 200 & $5(2.5 \%)$ & $22(11 \%)$ \\
\hline
\end{tabular}




\section{DISCUSSION}

Many research were conducted to find out the factors that could be, or contributing in, abortions in affected women all over the world. Many researchers found a lot of direct causes or contributing factors for abortion like infections, autoimmune diseases, toxins, congenital anomalies, hormones, or simply a trauma. ${ }^{1,12}$

This research was conducted to find out the infective rate of two of commonly distributed chronic and latent infections (toxoplasmosis and HSV) in selected sample of aborted women in Mosul city, and to find out if weather (climate) changes could affect the re-activation of infection with these microorganisms.

Two hundreds female patients with frequent miscarriage were included in this study. They were all sent to laboratory investigation at Al-Salam Teaching Hospital as part of a routine work for assessing possible causes for their abortions. To check for seasonal changes, the samples were collected as 100 blood samples in winter and 100 in summer. After collection, all samples were tested for active toxoplasmosis (Anti-toxoplasma gondii IgM antibodies) and active Herpes simplex virus infection (Anti-HSV IgM antibodies) to see if seasonal changes may or may not affect the reactivation of latent infections with these microorganisms.

Results showed that there were only 5 aborted women with active toxoplasmosis indicated by positive anti-toxoplasma IgM antibodies, including 2 patients in winter and 3 patients in summer. Which indicate no significant variance due to seasonal changes, and the cold or hot weather has minimal or no relation to infection activation. The rate of infection among this group was similar to some extent to the rate of infection in other localities in our country according to similar studies conducted in different cities and provinces. ${ }^{6,7}$

Results of HSV infection showed no variance in rate of infection due to seasonal changes among tested patients, and the rate of active infection were almost the same in both winter and summer, which indicate that there is minimal or no effect of the weather on infection activation. The rate of infection in this group of patients (11\%) were higher than the rate of infection in other localities in our country according to many studies conducted in different cities and provinces ${ }^{10,21]}$, which could indicate a real higher frequency of such infection in Mosul city or could be due to a relatively small sample size of the studies in this subject.

This study also indicates that the rate of active HSV was higher than the active toxoplasmosis $(11 \%$ versus $2.5 \%$ respectively) in frequently aborted women included in this study. This could indicate that HSV infection could be contributed to a higher rate of abortion than toxoplasmosis do.

\section{CONCLUSION}

The rate of active toxoplasmosis or HSV infection in frequently aborted women showed no relationship to seasonal change; and active HSV infection could be more related to abortion than toxoplasmosis in this group of tested patients.

\section{REFERENCES}

1-Giovanni Nigro, Manuela Mazzocco, Elisabetta Mattia, Gian Carlo Di Renzo, Gaspare Carta, \& Maurizio M. Anceschi. Role of the infections in recurrent spontaneous abortion. 2011. The Journal of Maternal-Fetal and Neonatal Medicine. DOI: 10.3109/14767058.2010.547963.

2-Gasanova TA. Laboratory diagnosis of sexually transmitted infections in chronic inflammatory diseases of the reproductive system. Zh Mikrobiol Epidemiol Immunobiol. 2001;3:60-63.

3-Marina Bujko, Vojin Sulovic, Vera Zivanovic', Rajko Dotlic, Ivana Bardic. Herpes simplex virus infection in women with previous spontaneous abortion. J. Perinat. Med.1988. 16.3:193-196.

4-Al-hamdani Muna M., Mahdi Nadham K. Toxoplasmosis among women with habitual abortion. Eastern Mediterranean Health Journal.1996. 3(2): 310-315.

5-Hayder A. L. Mossa. Toxoplasmosis in Iraqi Women: a Retrospective Study. Karbala J. Med.2009.2.8,9: 697-701.

6-Mohammed LJ, Al-Janabi MS. Seroprevalence of toxoplasmosis in aborted women in Babylon province. Iraq. Med J Babylon.2019. 16:188-91.

7-Hussein M. Abdullah, and Marwan A. Mahmood. Seroprevalence of Toxoplasma gondii among Pregnant Women in Erbil City/ Kurdistan Region/ Iraq. Polytechnic Journal.2017. 7.3:54-63.

8-Mariam K. Ali, Huda D. Hathal, Hala A. Almoayed. Prevalence and Diagnosis of Genital Herpes by Immunological and Molecular Study. Iraqi JMS.2018. 16.1: 4-7. 
9-Musa Nima Mezher, Fatima Abdulhussein Mejbel, Humam Kasem Hussein. Detection of Herpes Simplex -2 Virus in Women with Spontaneous Abortion in Al-Najaf City/lraq. J. Pharm. Sci. \& Res. 2018. 10.1:110-113.

10- Zainab Khalil Mohamed Aljumaili, Abdulghani Mohamed Alsamarai, WesamSuhailNajem. Seroprevalence of Herpes Simplex Virus Type 2 (HSV 2) in Women with Bad Obstetric History. American Journal of Dermatology and Venereology. 2013. 2.3: 31-38.

11- Ibrahim A. Naqid, Shivan H. Yousif, Nawfal R. Hussein. Seroprevalence of Rubella and Herpes Simplex Virus in Women with Miscarriage and Stillbirth in Zakho City, Kurdistan Region, Iraq: A Cross-Sectional Study. Women. Health. Bull. 2020. 7.1.

12- Goodyear HM; McLeish P; Randall S; Buchan A; Skinner GR; Winther M; Rolland J; Morgan G; Harper JI. Immunological studies of Herpes simplex virus infection in children with atopic eczema. Br J Dermatol. 1996.134(1):85-93.

13- Herbert AM; Bagg J; Walker DM; Davies KJ; Westmoreland D. Seroepidemiology of herpes virus infections among dental personnel. J Dent. 1995.23(6):339-42.

14- Langeland N; Haarr L; Mhalu F. Prevalence of HSV-2 antibodies among STD clinic patients in Tanzania. Int J STD AIDS. 1998.9(2):104-7.

15- Lin, T.M., S.P. Halbert and G.R. O'Connor. Standardized Quantitative Enzyme-linked Immunoassay for Antibodies to Toxoplasma gondii. J. Clin. Microbiol. 1980. 11. 6:675-681.

16- Markoulatos P; Fountoucidou P; Marinakis G; Krikelis V; Spyrou N; Vamvakopoulos N; Moncany ML. Clear detection and typing of Herpes simplex virus types 1 and 2 by an indirect ELISA assay: comparison with three different combined methods--capture ELISA, restriction enzymes, and polymerase chain reaction. J Clin Lab Anal.1997. 11(3):146-53.

17- Markoulatos P; Labropoulou V; Kordossi A; Krikelis V; Spyrou N; Moncany ML. A combined indirect ELISA and immunoblotting for the detection of intrathecalHerpes simplex virus IgG antibody synthesis in patients with herpes simplex virus encephalitis. J Clin Lab Anal. 1995. 9(5):325-33.
18- Roller, A., A. Bartlett and D.E. Bidwell. Enzyme Immunoassay with Special Reference ELISA Technique. J. Clin. Path. 1987. 31:507520.

19- Turune, H.J., P.O. Leinikke, and K.M. Saari. Demonstration of intraocular Synthesis of Immunoglobin G Toxoplasma Antibodies for Specific diagnosis of ToxoplasmicChorioretinitis by Enzyme Immunoassay. J. Clin. Microbiol. 1983. 17:988-992.

20- Voller, A., D.E. Bidwell, A., Bartlett, D.G. Flick, M Perkins and B. Oladshin. A Microplate Enzyme-immunoassay for Toxoplasma Antibodies. J. Clin. Path. 1976. 29:150-153.

21- Panagiotis Tsikouras, Theodora Deftereou, Xanthoula Anthoulaki, Anastasia Bothou, Anna Chalkidou, Fotini Gaitatzi, Ioannis Tsirkas, Arsou Chalil Bourazan, Eirini Bampageorgaka, George Stanulov, Elefterios Chatzimichael, Spyridon Michalopoulos, Panagiotis Petsidis, Georgios latrakis, Stefanos Zervoudis, Maria Lambropoulou, Werner Rath, Georgios Galazios. Induced Abortion and Spontaneous Early Pregnancy Loss - Focus on Management. 2019. DOI: 10.5772/intechopen.86194. 